\title{
Нові тенденції у тренувальному процесі спортсменів, що спеціалізуються в мотоциклетному кросі на мотоциклах 3 коляскою
}

\author{
Марія Сова \\ Володимир Шишка
}

Харківська державна академія фрізичної культури, Харків, Україна

\begin{abstract}
Мета дослідження полягає в обгрунтуванні методик спеціальної фрізичної підготовки спортсменів в мотокросі на мотоциклах з боковим причепом з урахуванням їх індивідуальних особливостей

Завдання дослідження: розробити методику підготовки спортсменів, що спеціалізуються в мотокросі на мотоциклах з коляскою з урахуванням специфріки взаємодії членів екіпажу.

Матеріал і методи: констатувальний педагогічний експеримент було організовано з метою порівняння основних техніко-тактичних показників змагальної діяльності світових лідерів та провідних українських екіпажів у кросі на мотоциклах з колясками, й обгрунтування, на чій підставі, методичних рекомендацій стосовно підготовки наших спортсменів до участі у міжнародних змаганнях найвищого рівня. Усі дослідження з метою порівняння результатів були організовані на одній і тій же трасі - єдиній сертифрікованій FIM в Україні мотокросовій трасі асоціації «Техноспорт» у м. Чернівиях довжиною 1620 м.

Результати: видима різниця в швидкості проходження дистанції світовими та українськими лідерами свідчить про істотно вищий рівень спеціальної, функціональної та технічної підготовленості перших, які на більш високих швидкостях долають

перешкоди на дистаниії, демонструючи високий рівень універсальності їхньої підготовленості. Виявлено, що спеціальна фрізична підготовка наших спортсменів $\epsilon$ надійним резервом підвищення їхньої спортивної результативності.

Висновки. Застосування методики побудови якісної структури змагальної рухової діяльності спортсменів у кросі на мотоциклах з колясками дало змогу встановити, що провідною руховою якістю є спеціальна спритність. Другою за значущістю в забезпеченні високого спортивного результату у кросі на мотоциклах з колясками $\epsilon$ загальна $і$ спеціальна витривалість членів екіпажу.
\end{abstract}

Ключові слова: мотокрос, вломлення,статичні зусилля,дихальні вправи.

\section{Вступ}

3 урахуванням специфіки взаємодії членів екіпажу на мотоциклі з коляскою при проходженні кросової дистанції до кожного з них пред'являються абсолютно різні вимоги як до рівня спеціальної фрізичної підготовленості, так і до змісту їхньої спеціальної фізичної підготовки [6]. На тіло пасажира діють набагато більші статичні навантаження, ніж на тіло водія, що спричинене специфрікою його робочих поз, їх швидкою зміною та великою амплітудою переходу з однієї робочої пози до іншої. На прямолінійних ділянках з'являється можливість часткового відпочинку пасажира, що пов'язане із деяким зниженням напруженості м'язів, що утримують позу, i забезпечує його готовність до нового швидкого переміщення. Статичні напруження м'язів спричиняють ускладнення дихання й погіршення циркуляції крові у напружених м'язах, що в цілому призводить до швидкої втоми і зниження точності рухових дій [1].

Природно, що саме ті чинники, які ускладнюють змагальну діяльність спортсменів у кросі на мотоциклах з колясками, визначають напрямки адекватної та адаптованої взаємодії засобів їхньої ЗФП та СФП. Засоби ЗФП застосовують для підвищення загального рівня функціонально- го забезпечення роботи гемо-кардіо-респіраторної сис- теми, як неспецифічної реакції організму на підвищення навантажень будь-якого характеру. Високий рівень такого функціонального забезпечення може досягатися будь- якими засоби впливу, що не вимагають урахування специфіки взаємодії членів екіпажу, як партнерів [3]. Що ж стосується СФП, то вона повинна ураховувати єдиний динамічний стереотип рухової взаємодії обох членів екіпажу і пайову участь у спільній та одночасній руховій діяльності різнихгруп їхніх м'язів - послідовність включення у роботу, величину й тривалість напруження тощо [7]. СФП повинна забезпечувати технічні дії, щодо керування транспортним засобом - мотоциклом. Така взаємодія можлива лише під час проходження траси при умові засвоєння конкретних елементів подолання її складних ділянок [12].

Зв'язок дослідження 3 науковими програмами, планами, темами. Дослідження виконувалися відповідно до плану науково-дослідної роботи кафедри зимових видів спорту, велоспорту та туризму Харківської державної академії фрізичної культури Міністерства освіти і науки України на 2019-2023рр. за темою «Оптимізація тренувального процесу в циклічних та екстремальних видах спорту» (номер державної реєстрації 0119U100439).

Мета дослідження полягає в обґрунтуванні методик спеціальної фізичної підготовки спортсменів в мотокросі на мотоциклах з боковим причепом з урахуванням їх індивідуальних особливостей

Завдання дослідження: Розробити методику підготовки спортсменів, що спеціалізуються в мотокросі на мотоциклах з коляскою з урахуванням специфіки взаємодії членів екіпажу.

\section{Результати дослідження}

На тіло пасажира діють набагато більші статичні навантаження, ніж на тіло водія, що спричинене специфікою його робочих поз, їх швидкою зміною та великою амплітудою переходу з однієї робочої пози до іншої [13]. На прямолінійних ділянках з'являється можливість часткового відпочинку пасажира, що пов'язане із деяким зниженням напруженості м'язів, що утримують позу, і забезпечує його готовність до нового швидкого переміщення. Статичні напруження м'язів спричиняють ускладнення дихання й погіршення циркуляції крові у напружених м'язах, що в цілому 


\section{СЛОБОЖАНСЬКИЙ НАУКОВО-СПОРТИВНИЙ ВІСНИК:}

\section{Матеріали XIX Міжнародної науково-практичної конференції «Фізична культура, спорт і здоров'я: стан, проблеми та перспективи»}

рухових дій. Кожна траса для мотокросу має унікальну кількість правих і лівих поворотів різної категорії складності (за $[2,4,9])$, що й визначають її характеристику за поворотами (П). Характеристика складності траси асоціації «Техноспорт» у м. Чернівцях за кількістю поворотів різної категорії складності наведена в табл. 1. За кількістю та категорією поворотів траса складна і повністю відповідає вимогам FIM до трас для проведення міжнародних мотокросів найвищого рівня. Вибір єдиної траси для організації констатувального експерименту дав змогу об'єктивно порівняти показники змагальної діяльності провідних зарубіжних і вітчизняних екіпажів на мотоциклах зколясками.

Усіх учасників педагогічного експерименту за спортивними результатами на етапах чемпіонатів світу та України 2014-2015 рр. було умовно поділено на чотири групи: світові лідери, світові аутсайдери, українські лідери та українські аутсайдери.

Порівняння середніх значень швидкостей входу в повороти, виходу з поворотів і часу їхнього проходження світовими й українськими лідерами вказує, що різниці між ними статистично значущі. Так, для $\mathrm{V}_{1}-\mathrm{W}=159<\mathrm{W}_{0,05}$ $=160$, для $\mathrm{V}_{2}-\mathrm{W}=172<\mathrm{W}_{0.10}=173$, а для $\mathrm{t}-\mathrm{W}=105<$ $\left.\mathrm{W}_{0.01}=147\right)$. Проте різниця між вказаними показниками залежить як від категорії складності поворотів, так і від сумарного кута повороту, що визначає його довжину. Так, різниця між середніми швидкостями входу у повороти другої категорії світовими та українськими лідерами $\Delta \mathrm{V}_{\text {, }}$ ср становить 10,2 км/год, різниця між середніми швидкостями виходу з поворотів другої категорії складності $\Delta \mathrm{V}_{2}$ ср становить 9,6 км/год а різниця між часом проходження поворотів другої категорії $\Delta \mathrm{t}{ }_{\mathrm{cp}}-2,94$ с (табл. 2); для поворотів третьої категорії складності вказані різниці станов- лять $\Delta \mathrm{V}_{1 \text { ср }}=8,0 \mathrm{kм} /$ год, $\mathrm{V}_{2 \text { ср }}=8,0 \mathrm{kм} /$ год, $\Delta \mathrm{t}_{\text {ср }}=2,20$ с, для поворотів четвертої категорії складності $-\Delta \mathrm{V}_{1 \mathrm{cp}}=4,5 \mathrm{~km} /$ год, $\mathrm{V}_{2 \text { ср }}=6,5 \mathrm{kм} /$ год, $\Delta \mathrm{t}_{\mathrm{cp}}=1,90 \mathrm{c}$, а для поворотів п'ятої категорії складності $-\Delta \mathrm{V}_{1 \text { ср }}=3,7$ км/год, $\mathrm{V}_{2 \text { ср }}=6,0$ км/год, $\Delta \mathrm{t}=1,40$ с відповідно

Видима різниця в швидкості проходження дистанції світовими та українськими лідерами свідчить про істотно вищий рівень спеціальної, функціональної та технічної підготовленості перших, які на більш високих швидкостях долають перешкоди на дистанції, демонструючи високий рівень універсальності їхньої підготовленості.

Доцільно зауважити, що недостатній рівень спеціальної фізичної пвдготовленості наших екіпажів призводить до того, що вини не в змозі на фоні наростаючої втоми утримувати потрібний час при подоланні різних категорій поворотів та інших перешкод траси незручні з позицій біомеханіки м'язового скорочення, але оптимальні з точки зору стабілізації підсистеми СМ статичні робочі пози - стійки (наприклад, при подоланні різних поворотів цей час коливається від 7,3 до 8,2 с (для світових лідерів - це 4,5-6,5 c,). Унаслідок цього порушується довантаження відповідних коліс мотоцикла, що змущує українські екіпажі від кола до кола знижувати швидкість проходження окремих елементів траси, що істотно погіршуе спортивний результат. Тому спеціальна фрізична підготовка наших спортсменів до описаних вище умов змагальної діяльності $€$ надійним резервом підвищення їхньої спортивної результативності.

Це підтверджує наше припущення як про неналежний рівень їхньої спеціальної підготовленості, так і про нестабільність техніко-тактичної майстерності, і дає змогу окреслити напрямки подальшої підготовки українських екіпажів на мотоциклах з колясками до всеукраїнських

Таблиця 1

Характеристика складності мотокросової траси асоціації «Техноспорт» (м. Чернівці) за кількістю поворотів різної категорії складності

\begin{tabular}{|c|c|c|c|c|}
\hline $\begin{array}{c}\text { Номери поворотів } \\
\text { за порядком }\end{array}$ & $\begin{array}{c}\text { Умовне позначення } \\
\text { повороту }\end{array}$ & $\begin{array}{c}\text { Напрямок } \\
\text { повороту }\end{array}$ & $\begin{array}{c}\text { Категорія } \\
\text { складності } \\
\text { повороту } \\
\text { (бали) }\end{array}$ & $\begin{array}{c}\text { Кількість поворотів } \\
\text { певної категорії } \\
\text { складності }\end{array}$ \\
\hline $1,3,10$ & $\mathrm{P}$ & Правий & 2 & 2 \\
\hline 6,7 & $\mathrm{P}$ & Правий & 4 & 1 \\
\hline 12 & $\mathrm{P}$ & Правий & 5 & 2 \\
\hline 4,9 & $\mathrm{~L}$ & Лівий & 2 & 1 \\
\hline 14 & $\mathrm{~L}$ & Лівий & 3 & 5 \\
\hline
\end{tabular}

Таблиця 2

Різниця між середніми значеннями показників проходження поворотів траси мотокросу асоціації «Техноспорт» у м. Чернівцях світовими (n = 10) та українськими $(n=10)$ лідерами

\begin{tabular}{|c|c|c|c|c|}
\hline \multirow{2}{*}{ № з/п } & \multirow{2}{*}{$\begin{array}{c}\text { Категорія склад-ності } \\
\text { повороту }\end{array}$} & \multicolumn{3}{|c|}{ Показники проходження повороту } \\
\cline { 3 - 5 } & 2 категорія & $\Delta \mathrm{V}_{1 \mathrm{cp}}, \mathrm{\kappa m} /$ год. & $\Delta \mathrm{V}_{2 \mathrm{cp}}$, км/год. & $\Delta \mathrm{t}_{\mathrm{cp}}, \mathrm{c}$ \\
\hline 1 & 3 категорія & 10,2 & 9,6 & 2,94 \\
\hline 2 & 4 категорія & 8,0 & 8,0 & 1,90 \\
\hline 3 & 5 категорія & 4,5 & 6,5 & 1,40 \\
\hline 4 & & 3,7 & 6,0 & \\
\hline
\end{tabular}




\section{Матеріали XIX Міжнародної науково-практичної конференції «Фізична культура, спорт і здоров'я: стан, проблеми та перспективи»}

міжнародних змагань найвищого рівня.

Як ЗФП, так і СФП членів екіпажу повинна бутиспрямована на удосконалення їхніх силових якостей, бистроти, витривалості, координаційних здібностей і спритності, які повинні забезпечувати специфічну рухову діяльність спортсменів на мотоциклі з коляскою. Кожна із зазначених рухових якостей має різну за обсягом, тривалістю й напруженістю частку у забезпеченні такої рухової діяльності [8].

Для належного рівня підготовки гемо-кардіореспіраторних механізмів доцільно використовувати такі засоби, як повторне дихання у замкнутий простір з обмеженим об'ємом, а також дихання під водою на глибині через гофрровану трубку, що з'єднує дихальну систему спортсмена з атмосфрерним повітрям. Для забезпечення більш ефективної циркуляторної функції кровоносних судин у напружених скелетних м'язах можна рекомендувати статичні вправи різної тривалості у таких робочих позах водія і пасажира, які забезпечують стереотип їхньої змагальної рухової діяльності. В усіх випадках вимогою, що забезпечить ефективність застосованих засобів, було обмеження величини й тривалості навантажень до третини від їхнього можливого максимуму. Ефективністьтакого підходу до спеціальної фрізичної підготовки екіпажів на мотоциклах з колясками підтверджена численними емпіричними результатами [10], морфо-функціональною організацією режиму роботи узгодженої взаємодії систем організму [5] і математичним моделюванням роботи систем організму [11]. Ефективне узгодження взаємодії функціональних систем організму і $є$ основою побудови оптимального алгоритму процесу адаптації до застосованих тренувальних навантажень

\section{Висновки /Дискусія}

Застосування методики побудови якісної структури змагальної рухової діяльності спортсменів у кросі на мотоциклах з колясками дало змогу встановити, щопровідною руховою якістю $є$ спеціальна спритність. Однак більш глибоке уявлення про особливості прояву цієї якості вимагає розгляду її не тільки, як характеристики явища, а й як процесу, перебіг якого має бути сумірним із динамікою перебігу змагальних ситуацій. А спеціальна спритність пасажира за обсягом добору і бистроти її прояву повинна перевершувати прояв цієї-ж якості у водія. Другою за значущістю в забезпеченні високого спортивного результату у кросі на мотоциклах з колясками є загальна і спеціальна витривалість членів екіпажу.

Найбільш ефективний прояв оптимального співвідношення рухових якостей спостерігається під часпрояву рівноважної напруги, відповідної необхідній мірі готовності до забезпечення потрібної інтенсивності рухової діяльності. В усіх інших випадках спостерігається ріст числа і грубості помилок, допущених членами екіпажу при подоланні траси мотокросу. При цьому проявляється скутість рухів та асиметрія у співвідношенні процесів збудження та гальмування, що істотно порушує динамічний стереотип поведінки в екстремальних ситуаціях змагальної діяльності.

Перспективи подальших досліджень полягають в оптимізації тренувального процесу спортсменів в мотокросі на мотоциклах з коляскою, яка направлена на розробку індивідуальних програм, індивідуального контролю готовності спортсмена до здійснення змагального навантаження.

Конфлікт інтересів. Автори заявляють, що немає конфлікту інтересів, який може сприйматися таким, що може нанести шкоду неупередженості статті.

Джерела фінансування. Ця стаття не отримала фрінансової підтримки від державної, громадської або комерційної організації.

\section{Список посилань}

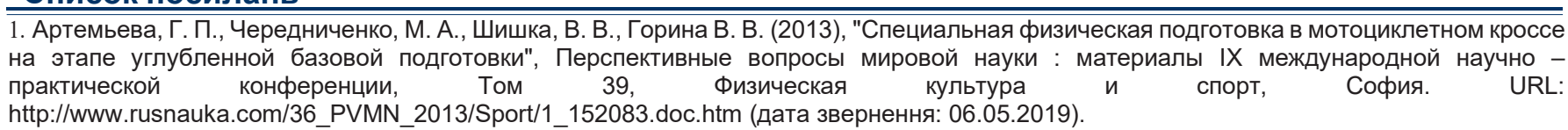

2. Друзь, В. А., Чередниченко, М. А., Шишка, В. В., Горина, В. В. (2015), "Система контроля качественной структуры специальной физичекой подготовки в мотокроссе на мотоциклах с коляской", Слобожанський науково-спортивний вісник, Харків, С.40-45.

3. Пугач, Я. И., Чередниченко, М. А., Друзь, В. А., Шишка, В. В. (2014), "Инновационные технологии в подготовке спортсменов в технических видах спорта", Проблеми та перспективи розвитку спортивно-технічних і прикладних видів спорту та екстремальної діяльності: материалы II Всеукраїнської науково-практичної конференції с міжнародною участю, Харків, С.18 -22.

4. Пугач, Я. И., Друзь, В. А., Чередниченко, М. А., Шишка, В. В. (2015), "Влияние согласованности действий спортсменов, специализирующихся в мотокроссе мотоциклов с боковым прицепом на спортивный результат", Молода спортивна наука України, Выпуск 19,T I, С.196 -20.

5. Сова, М. А., Шишка, В. В. (2019), "Удосконалення методики тренування спортсменів високої кваліфікації в мотоциклетному спорті, що спеціалізуються в мотокросі на мотоциклах з коляскою", Основи побудови тренувального процесу в циклічних видах спорту: матеріали конференції, Харків, С. 136-138.

6. Сова, М. А., Шишка, В. В. (2019), "Аналіз підготовленості українських гонщиків, що спеціалізуються в мотоциклетному кросі на мотоциклах з коляскою", Науковий часопис Національного педагогічного університету імені М.П. Драгоманова, Серія 15, Науково педагогічні проблеми фрізичної культури (фрізична культура і спорт): зб. наук. пр., Київ, Вип. 6 (114)19, С. 83 - 87

7. Шишка, В. В., Чередниченко, М. А., Градусов, В.О. (2015), "Психоффізіологічні показники спортсменів високої кваліфрікації, які спеціалізуються в мотоциклетному спорті", Фізична культура, спорт та здоров'я: матеріали XV між нар. наук.-практ. конф., Харків, С.129131

8. Bogdanow, O. A., Cygankow, E. S. (1989), Sportowa jazda samochodem. Warszawa : Wydawnictwo Komunikacji i Łączności, 112 p.

9. Buhlmann, K. (2003), Perfekt Auto fahren - Tipps, Tricks und Techniken: Motorbuch Verlag Pietsch, 190 p.

10. Buhlmann, K. (2005), 40 Jahre Rallyesport Evo 2 Buhimann. Stuttgart : Motorbuch Verlag Pietsch, 198 p.

11. Hough, D. L. (2011), Motocyklista doskonały. Droga do mistrzostwa. Hough. Warszawa, 2010. 56 p.

12. Motocykle / red. Jędrzejewski K/ Warszawa, 2011.

13. Szczerbicki, T. (2012), Przedwojenne samochody i motocykle. Najpiękniejsze fotografie. Warszawa, $127 \mathrm{p}$ 


\section{СЛОБОЖАНСЬКИЙ НАУКОВО-СПОРТИВНИЙ ВІСНИК:}

\section{Матеріали XIX Міжнародної науково-практичної конференції «Фізична культура, спорт і здоров'я: стан, проблеми та перспективи»}

Аннотация. Мария Сова, Владимир Шишка. Новые тенденции в тренировочном процессе спортсменов, специализирующихся в мотоциклетном кроссу на мотоциклах с коляской. Цель исследования заключается в обосновании методик специальной фризической подготовки спортсменов в мотокроссе на мотоциклах с боковым прицепом $c$ учетом их индивидуальных особенностей. Задачи исследования: разработать методику подготовки спортсменов, специализирующихся в мотокроссе на мотоциклах с коляской с учетом специфики взаимодействия членов экипажа. Материал и методы исследования: констатирующий педагогический эксперимент был организован с иелью сравнения технико-тактических показателей соревновательной деятельности мировых лидеров и ведущих украинских экипажей в кроссе на мотоциклах с колясками, и обоснование, на этом основании, методических рекомендаций по подготовке наших спортсменов к участию в международных соревнованиях самого высокого уровня. Результаты видимая разница в скорости прохождения дистанции мировыми и украинскими лидерами свидетельствует о существенно более высокий уровень специальной, функциональной и технической подготовленности первых, которые на более высоких скоростях преодолевают препятствия на дистанции, демонстрируя высокий уровень универсальности их подготовленности. Выявлено, что специальная физическая подготовка наших спортсменов является надежным резервом повышения их спортивной результативности. Выводы. Применение методики построения качественной структуры соревновательной двигательной деятельности спортсменов в кроссе на мотоциклах с колясками позволило установить, что ведущей двигательной качеством есть специальная ловкость. Второй по значимости в обеспечении высокого спортивного результата в кроссе на мотоциклах с колясками общая и

специальная выносливость членов экипажа.

Ключевые слова: мотокросс, вломлення, статические усилия, дыхательные упражнения

Abstract. Maria Sova, Vladimir Shishka. New trends in the training process of athletes specializing in motorcycle crosscountry racing with sidecar motorcycles. The purpose of the study is to justify the methods of special physical training of athletes in motocross on motorcycles with a side trailer, taking into account their individual characteristics. Research objectives: To develop a methodology for training athletes specializing in motocross motorcycles with a sidecar, taking into account the specific interaction of crew members. Material and research methods: a pedagogical experiment was organized in order to compare the technical and tactical indicators of the competitive activity of world leaders and leading Ukrainian crews in cross-country motorcycle riding with wheelchairs, and justification, on this basis, of methodological recommendations for preparing our athletes for participation in international competitions the highest level. Results apparent difference in the speed of the distance between world and Ukrainian leaders indicates a significantly higher level of special, functional and technical preparedness of the former, which at higher speeds overcome obstacles at a distance, demonstrating a high level of universality of their preparedness. It has been revealed that the special physical training of our athletes is a reliable reserve for increasing their sports performance. Conclusions. Application of the methodology for constructing a qualitative structure of competitive motor activity of athletes in cross-country on motorcycles with wheelchairs made it possible to establish that the leading motor quality is special agility. The second most important in ensuring a high sports result in crosscountry on motorcycles with wheelchairs is the general and special endurance of crew members.

Keywords: motocross, breaking, static effort, breathing exercises.

\section{References}

1. Artemeva, G. P., Cherednichenko, M. A., Shishka, V. V., Gorina V. V. (2013), "Special physical training in a motorcycle cross-country at the stage of advanced basic training", Perspektivnyie voprosyi mirovoy nauki : materialyi IX mezhdunarodnoy nauchno - prakticheskoy konferentsii, Tom 39, Fizicheskaya kultura i sport, Sofiya. URL: http://www.rusnauka.com/36_PVMN_2013/Sport/1_152083.doc.htm (дата звернення: 06.05.2019). (in Russ).

2. Druz, V. A., Cherednichenko, M. A., Shishka, V. V., Gorina, V. V. (2015), "The control system of the quality structure of special physical training in motocross on motorcycles with a sidecar", Slobozhanskyi naukovo-sportyvnyi visnyk, Kharkiv, pp.40-45. (in Russ).

3. Pugach, Ya. I., Cherednichenko, M. A., Druz, V. A., Shishka, V. V. (2014), "Innovative technologies in the training of athletes in technical sports", Problemy ta perspektyvy rozvytku sportyvno-tekhnichnykh i prykladnykh vydiv sportu ta ekstremalnoi diialnosti: materialy II Vseukrainskoi naukovo- praktychnoi konferentsii s mizhnarodnoiu uchastiu, Kharkiv, pp.18 -22. (in Russ).

4. Pugach, Ya. I., Cherednichenko, M. A., Druz, V. A., Shishka, V. V. (2015), "The influence of the coordination of actions of athletes specializing in motocross motorcycles with a side trailer on a sports result". Moloda sportyvna nauka Ukrainy, Vypusk 19,T. I, pp.196 -20. (in Russ)

5. Sova, M. A., Shyshka, V. V. (2019), "Improvement of training methods for high-skill athletes in motorcycle sports specializing in wheelchair motorcycle racing", Osnovy pobudovy trenuvalnoho protsesu v tsyklichnykh vydakh sportu: materialy konferentsii, Kharkiv, pp.136-138. (in Ukr) 6. Sova, M. A., Shyshka, V. V. (2019), "Preparedness analysis of Ukrainian riders specializing in motorcycle cross-country on motorcycles with wheelchairs", Naukovyi chasopys Natsionalnoho pedahohichnoho universytetu imeni M.P. Drahomanova, Seriia 15, Naukovo - pedahohichn problemy fizychnoi kultury (fizychna kultura i sport): zb. nauk. pr., Kyiv, Vyp. 6 (114)19, pp. 83 - 87. (in Ukr).

7. Shyshka, V. V., Cherednychenko, M. A., Hradusov, V.O. (2015), "Psychophysiological indicators of high-skilled athletes specializing in motorcycle sports", Fizychna kultura, sport ta zdorovia: materialy XV mizh nar. nauk.-prakt. konf., Kharkiv, pp.129-131. (in Ukr).

8. Bogdanow, O. A., Cygankow, E. S. (1989), Sportowa jazda samochodem. Warszawa : Wydawnictwo Komunikacji i Łączności, 112 p. (in Eng). 9. Buhlmann, K. (2003), Perfekt Auto fahren - Tipps, Tricks und Techniken: Motorbuch Verlag Pietsch, 190 p. (in Eng).

10. Buhlmann, K. (2005), 40 Jahre Rallyesport Evo 2 Buhimann. Stuttgart : Motorbuch Verlag Pietsch, 198 p. (in Eng).

11. Hough, D. L. (2011), Motocyklista doskonały. Droga do mistrzostwa. Hough. Warszawa, 2010. 56 p. (in Eng).

12. Motocykle / red. Jędrzejewski K/ Warszawa, 2011. (in Eng).

13. Szczerbicki, T. (2012), Przedwojenne samochody i motocykle. Najpiękniejsze fotografie. Warszawa, 127 p. (in Eng)

Received: 11.11.2019.

Published: 30.12.2019.

\section{Відомості про авторів / Information about the Authors}

Сова Марія Анатоліївна: Харківська державна академія фрізичної культури: вул Клочківська 99, м. Харків, 61058, Україна.

Сова Мария Анатольевна: Харьковская государственнаяакадемия физической культуры: ул. Клочковская 99, г. Харьков, 61058, Украина. Sova Maria: Kharkiv State Academy of Physical Culture: Klochkivska 99, Kharkiv, 61058, Ukraine.

ORCID ORG/0000-0003

2997-3407 E-mail:

mechta2509@bk.ru

Шишка Володимир Володимирович: Харківська державна академія фізичної культури: вул Клочківська 99, м. Харків, 61058, Україна.

Шишка Владимир Владимирович: Харьковская государственная академия физической культуры: ул. Клочковская 99, г. Харьков

61058, Украина.

Volodymyr Shishka: Kharkiv State Academy of Physical Culture: Klochkivska 99, Kharkiv, 61058, Ukraine.

ORCID.ORG/0000-0002-2783-1870

E-mail:bobka_bobka@inbox.ru 